\title{
Values and Behaviour: The Literary Concept of "Bosom" in the Akan Culture
}

Peter Arthur ${ }^{1}$

${ }^{1}$ Department of English, Kwame Nkrumah University of Science and Technology, Kumasi-Ghana.

\begin{abstract}
This paper sees the Akan concept of "bosom", translated into English as "lesser Akan people in the construction of what is known as "bosom". This study recourse to qualitative research methods in gathering data, the researcher immersing in the culture through formal and informal interviews and participant observation. The study also goes further to use the literary stylistics approach in analyzing the data. The findings are that man makes the taboos and the lesser gods execute the punishment. Again, taboos are values which constitute the tracks on which the society moves. These values "disguised" as "bosom" work, thanks to the fear factor in the Akan concept of "bosom", making Akans literally worship these values in the form of "bosom".
\end{abstract}

Correspondence:

Peter Arthur

Email: pitah_7@yahoo.com

Publication History

Received 27th July, 2021,

Accepted 27th September, 2021,

Published online 30th September, 2021.

Keywords: Cultural values, taboos, punishment, Akan lesser gods, stylistics

(C) 2021 The Author(s). Published and Maintained by Noyam Publishers.

This is an open access article under the CCBY license (http://creativecommons.org/licenses/by/4.0/).

\section{INTRODUCTION}

Both written and unwritten languages, according to the hypothesis of linguistic relativity, ${ }^{1}$ have their inventories of characteristics that give them their individual identity premised on the environment and the fact that meaning is contingent on the environment is not in doubt here. In literary theory, one could have intertextuality when the meaning of the textual environment is as crucial as the text in question. ${ }^{2}$ Indeed, literary history and criticism are replete with such examples and they all demonstrate the importance of the link between the environment and language.

This concept of the relationship between the environment and language occasioned Sapir and Whorf to investigate the extent to which the environment can influence the linguistic and even the social behavior of a group of people. Sapir postulates that the " 'real world' is to a large extent unconsciously built up on the language habit of the group." "The "real world" in this context is the environment. He further claims, "an intellectual system embodied in such language shapes the thought of the speakers in a quite general way". ${ }^{4}$ By implication therefore, there is a strong link between the thought of speakers of a language and the intellectual

1 John.Joseph, From Whitney to Chomsky: Essays in the History of American Linguistics. (Amsterdam: John Benjamins, 2002).

2 Meghan Becher-Leckrone, Julia Kristeva and Literary Theory,(London, Palgrave Macmillan, 2005).

3 Edward Sapir. quoted in Paul Kay and Willet Kempton, What is Sapir-Whorf Hypothesis? American Anthropologist. Vol. 86, no 1, (1951): 65-79.

4 Sapir, What is Sapir-Whorf Hypothesis? 65-79. 
system of that language. Whorf has also produced extensive materials on habitual thought and behavior and its relation to language. ${ }^{5}$ That linguistic differences based on the differences in the environment could induce different cognition is key to the analysis of this paper and reference to the environment within the context of this paper is more about the culture. Particular reference is being made to cultural and ideological environments that influence the structures of language. Naom Chomsky is quite clear about this. To him, what a group of people do with language reflects the environment or the modes of thought of that group. ${ }^{6}$ One important environmental aspect that sustains human life, in this context, is cultural values. Even though certain critics express their doubt in the study of cultural value as an academic exercise, ${ }^{7}$ they cannot deny the fact that every culture or environment has its own values that drive it. One cannot but agree with Parson when he defines value as abstract concepts that simply provide a referent for thought and action that becomes the norm for society, ${ }^{8}$ thus lending further support for Sapir and Whorf's cognitive linguistics that the thought and actions of a group of people inform the signification system of their language and the Akan culture is no exception. This, therefore, buttresses Lazzeri's definition of behavior as the pattern of actions by a group of people over time. ${ }^{9}$

The Akan culture, therefore, has a unique way of influencing the concepts and signification system in the Akan language. Countless works have been done by Ghanaians and foreigners with regard to the role language plays in Ghanaian culture. In reference to Sapir and Whorf's position that the social world shapes what people do and say, Kofi Agyekum defines and contextualizes "ntam" as a reminiscential oath by evocation unique to the Akans. ${ }^{10}$ It is a language that defines the Akan culture. Charles Marfo and Solace Yankson ${ }^{11}$ support Abena Dolphyne ${ }^{12}$ in her description of Akan syllabicity and tonality and also supports her postulation that even though other African languages are tonal, Akan tones behave differently and behave in response to specific Akan cultural contexts. Kwesi Yankah, in a magnificent manner, discusses how the environment informs the Akan proverbs. ${ }^{13}$ There is however a lacuna in the area of how word-formation reflects the link between the environment and the linguistic spaces. This paper, using the qualitative research approach, sets out to investigate the role Akan poetics play in revealing beliefs and the philosophy that used to, but of little influence today, shape the thinking of the Akan people for a better social organization.

\section{METHODOLOGY}

This research employed the use of the qualitative approach of collecting data. The data was collected from some Akan communities in Kumasi, Yamoransah and Accra, where Akan is more or less a second language. The research spanned two years, relying on a participant observation approach which enabled the researcher to interact with the indigenes quite frequently. The researcher also took the opportunity of meeting the indigenes to conduct unstructured interviews comprising the dyadic, triadic and focus group discussions. Being an indigene himself easily convinced the indigenes to say whatever they knew about the topic but in doing so, he observed all the scientific approaches in ethnography to be sure all biases are eliminated to the barest minimum. The researcher randomly selected participants who were males, females, young and old. A diary was kept to note their attitudes and reactions to the interviews, and the researchers transcribed and translated every interview into English using the literal translation approach. The data of this study supports the theory of Linguistic relativity which says cultural environment serves as the intertext for the language of the people.

\footnotetext{
5 Benjamin Lee Whorf, Science and Linguistics. In Language. Thought and Reality. John B. Caroll, ed. Cambridge, Mass: M. I. T. orig. pub. Technology Review. Vol. 42, (1956) : 229-231, 247-248.

6 Naom Chomsky, Language and Mind. (Harcourt Brace Jovanovich, Inc, 1972).

7 Florence Kluckhohm and Fred Strodtbeck, quoted in Spates, J. L. The Sociology of Values, Annual Review in Sociology, Vol. 9, (1961): 27-49.

8 Talcott Parson. quoted in Spates, J. L. The Sociology of Values, Annual Review in Sociology, Vol. 9,. (1961): $27-49$.

9 Filipe Lazzeri, F. On defining behavior: Some notes, Behaviour and Philosophy, Vol. 42, (2014): 65-82

${ }_{10}$ Kofi Agyekum. Ntam 'reminiscential oath' taboo in Akan, Language in Society, Vol 33, (3), (2004): $317-342$

${ }^{11}$ Charles Marfo and Solace Yankson. The Structure of the CCV Syllable of Akan. Concentric: Studies in Linguistics, 34 (2), (2008): 85-100.

12 Abena Dolphyne. The Akan (Twi-Fante) Language.: Its Sound System and Tonal Structure.(Accra: Ghana Universities Press, 1988).

${ }^{13}$ Kwesi Yankah. The Proverb in the context of Akan rhetoric; a theory of proverb praxis, (New York, Bern, 1989).
} 
This theory naturally constitutes the theoretical framework of this study and the analytical framework is literary stylistics. The discussion of the study throws more light on the literature on the relationship between the Akan cultural environment and the Akan language.

\section{DISCUSSION}

First, the emic meaning is very important in this study so a lot of Akans were asked to define "bosom". Seated comfortably on a chair, an Akan professor of French in his eighties defined "bosom" as the worship of stone. ${ }^{14}$ This contribution reflected the opinion of a lot of Akans interviewed. What was worth considering in this definition was that it did not mention "bosom" as being a concept of a spiritual entity, "lesser god", generally translated into English.

Other Akan participants, some of whom reside in Kumasi but most of whom are in other regions of the country, especially in the Greater Accra region, were very emphatic that "bosom" means the worship of value or something valuable. Kwame Nsiah Appau, the ace hiplife musician by the name Okyeame Kwame puts it this way:

Bosom ye adec a esom bo. Se adee som bo ma wo a, wope, wodi no ni na wohwe no yie. Yen mpanimfor som bosom eseane se na wogye abosom no di na wope abosom on so ascm. Enam saa nti, wodi nee abosom no ka no so. Eno nti, na abosom no tumi bo mpanimfor noho ban. ${ }^{15}$

\section{Translation}

Bosom is something valuable and if you value something, you love it, you respect it and you keep it well. Our forefathers worshipped gods because they believed in and loved the gods. On the account of that, they followed what the gods told them. No wonder, the gods were able to protect and keep our forefathers well.

What this famous musician in Ghana is saying is real food for thought. One: he did not make any reference to the common knowledge of the spiritual connotation of "lesser gods." Two: that the forefathers loved the gods and followed whatever the gods told them. Three: The gods, on the ground of the relationship they had with the forefathers were able to take proper care of the forefathers. And of even more interesting consideration is the fact that the two main definitions of "bosom", which according to the data is enough representation of what the participants are saying, present the concept of "worship" as a first option definition and not the spiritual meaning of "lesser gods". And indeed, for most of the participants and respondents, the spiritual concept of "lesser gods" was not the first option definition. Again, while Professor Opoku Agyeman and others were in unison about the worship of "stone", those who belonged to the school of thought of Kwame Nsiah Apau opined the worship of value or something valuable. ${ }^{16}$. This puts forward two objects of worship: the stone and an object of value. ${ }^{17}$ For the purpose of this paper, the researcher uses the worship of stone/ something of value when referring to the two definitions. Otherwise, he will be specific by referring to the worship of stone or the worship of value depending on the side of the debate that is being analyzed. To investigate the cultural meaning of "bosom", therefore, this paper interrogates the morphology that produces the noun phrase "bosom" but in doing that there is a need to start with the syntactic structure of "som+bo" which etymologically, is the source of "bosom".

\section{Nominalizing the verb phrase "som bo"}

The English translation of "som bo", to worship stone/an object of value may appear absurd in modern Akan because the expression has undergone a lot of meaning processes to such an extent that the original meaning, as indicated above, is gradually fading away. But it is important to go back to the original meaning and work

${ }^{14}$ Interview with Prof Opoku Agyeman in KNUST, Kumasi, 20/11/2020.

15 Interview with Kwame Nsiah Apau, Accra, 25/11/2020.

16 Interview with Kwame Nsiah Apau, Accra, 25/11/2020.

17 Patricia Ann Turrisi, ed. Pragmatism as a Principle and Method of Right Thinking: the 1903 Harvard Lectures on Pragmatism by Charles Sanders Peirce. (State University of New York Press, Albany, New York, 1997). 
through the meaning processes that give the modern meaning, having recourse to stylistics, investigating the "deep meaning through the surface form", from the syntactic to the discourse level. ${ }^{18}$ This paper starts by using the inverted form of "bo + som" thus "som+bo". The reason is that "bo+som" is a morphological structure, that is, "the sequence of determinant and determinatum for the combination in question." 19 This could mean a lot of things but for this analysis, the determinant is the head and the determinatum is the complement.

In the English language, the inflectional morphology "ing" added to the base "worship" makes it a gerund and according to the theory of headedness, the meaning of the phrase, "worshipping stone/values" centers around "worshipping" therefore "worshipping" is the head of the phrase. Thus, this is a noun phrase. The Akan language, however, presents the gerund construction in a different way. There is a switch in the subject-verb position. Thus, in "som+bo" as in "sika som bo", money is of value, the gerund construction becomes "bo a sika som", the worth of money. The former, "sika som bo" is a sentence and the "som" is a finite verb having "bo" as the object. In the latter construction "bo a sika som" however, "som" loses its finiteness and changes from a verb to a noun. In the latter construction, the complement "a sika" is gotten from the phrase, which becomes "bo+som". Similarly, there is "bo a cboว som" in Asante Twi, "bo a bo som" in Fante and the same "bo a bo som" in Akwapim Twi. The complement "a cboo" needs to be removed to get "bo+som". The theory of headedness indicates that "worshipping" is the head of this phrase and it means one worships what is of value and in this context, the object of value is the stone/value. A process of such nominalization in Akan is a derivative of the verb-object component of the sentence. It provides constructions such as "nya kwan" as in "Papa no nya kwan", (the man has an opportunity). The verb-object position is switched over to construct the gerund form to become "akwnya". It is the same in an expression like "bo+din" and its associated noun form, "dinbo", "di+atem" and its associated noun form, "atennie", "suro+Nyame" and its associated noun form "Nyamesuro" and the list is unremitting. There is a need to state here, however, there are other ways of constructing the noun form from the verb in Akan but for the purpose of this paper, the researcher concentrates on this nominalization process for the sake of staying focused on the topic.

There is a big question that scholars are faced with: why should the Akan language not employ a term that can encapsulate the spiritual connotation of "bosom" as is generally believed? Why does the Akan language nominalize the verb "som", to worship, and add the complement "bo" to connote (is it denote?) such a huge cultural concept like a pantheon of gods on their land? Why the worship of stone/value? There is a need to sort out the diverging and converging discourses on "stone" and "value" and to get answers to the questions raised.

This is where the symbolic communication comes in; the stone is physically a hard material and to support this notion the Akans say "nsuo beyc bos decn", to wit, water cannot do anything to the stone. The Akans also say "Jbo pae a yenpam", to wit, a broken stone cannot be mended. The hard nature of the stone, therefore, suggests something that is enduring and quite frankly something of value should not be just a "flash in the pan' but enduring and lasting. The stone, therefore, suggests quality or perfection.

There is now a need to apply the same approach in the process of meaning to Kwame Nsiah Apau's rendition. For him, "bo som" is worshipping what is valuable or in short, worshipping value. Here again the gerund "worshipping" is the head of the phrase and "value" provides the context of "worshipping". This time, "worshipping" has the complement "value" but the abstract of value; anything perfect, sublime and quintessential. And again, that is quality or perfection. So even though the definition provided by Prof. Opoku Agyemang is in the minority of opinions among Akans, it still has the same meaning as the definition provided by Kwame Nsia Apau, which is more popular among the Akans. The two definitions have the same concept of perfection in value.

\section{Naming of the concept of "bosom"}

Of particular interest in this analysis is the naming of the concept of "bosom". Naming is an old practice in all cultures but as a field of study, especially in linguistics, most studies have centered on proper names. Onomastic theories speak of naming as designating abstract and concrete nouns, including proper and common nouns. To use a derivative, "bo+som", from "som bo" actually satisfies the pragmatics of Pierce's concept

${ }_{18} \mathrm{Yu}$ Huang. The Application of Stylistic Analysis in College English Teaching, Advances in Economics, Business and

Management Research, volume 75,(2019) : 554-557.

19 Pavol Stekauer, and Rochelle Lieber, eds. Handbook of Word-formation, ( Dordredtch: Springer, 2005). 
of the iconic, the indexical and the symbolic in naming but as observed earlier, why not a term capturing the spiritual nature of these "lesser gods", especially considering the huge power capital the "lesser gods" have in Akan societies? ${ }^{20}$ That means that in the order of meanings, "som bo", worshipping stone/value, comes before any spiritual description of the "bosom". By implication, therefore, in talking about the definition of the "bosom", the etymological relevance of the words "worship" and "value" is of prime importance.

To throw more light on the fact that the core meaning of "bosom" is the worship of value, it is necessary to look at some deities in the Akan community, their classification and what they can do. The Nzema, just like all the other Akans, equate the Sky god (Nyamenle or Nyame in Fante and Asante and Akwapim Twi), to the Christian God and the Earth goddess, Asaase Yaa. Ringwald divides the lesser gods into three categories: omanabosom (town and land deities, abusua abosom (clan and family deities) and akomfo abosom (deities of diviners). ${ }^{21}$ It is important once again to point out that the two on top of the hierarchy, that is the Sky god and Earth goddess, are not part of this analysis because they are not lesser gods in the Akan definition. In fact, they have no shrines. ${ }^{22}$ The lesser gods are those taxonomized by Ringwald and their functions are tied to their locations. ${ }^{23}$

\section{Localities and functions of Akan lesser gods}

The main function of the Akan lesser gods is supposed to be for social order and social peace. Of course, there are other functions like helping the local people win wars or aid women in the localities to have babies, but this discussion will indicate that all these functions come down to peace in the society. The lesser gods are distributed according to the value needs of the locality.

Akonedi (a shrine) is located in Larteh Kubease in the Eastern Region of Ghana and she administers justice to the people of Larteh. Nana Adade Kofi (another shrine) is located in the Guan area in Ghana and is supposed to be the source of strength and perseverance for the people. Asuo Tano which spans from the Bone East region to the Western South Region of Ghana presides over the social order in such areas. Nana Obo Kwesi, a war deity from the Fanteland in Ghana, abhors evildoers. Antoa Nyamaa is in the Ashanti Region and hates injustice and dishonesty and will quickly deliver justice in favor of the innocent by killing the wrongdoer. The same can be said of Pataangye of the Western South Region. Bazomgbəke is a Nzema deity who hates impurity caused by sexual misconduct, physical uncleanliness and incest and does not delay in punishing offenders. All these gods have specific social assignments that instill order and peace in the society.

\section{The assignment of the lesser gods}

The assignment of the lesser gods, from the above, it is believed, is to ensure certain values are adhered to in the community for easy social organization. The "bosom" is a representative of the local value. Each community has its own set of values. If one goes to a community, even though all human values in the community are cherished, the community may place a premium on some more than others. In some communities, the values are represented by the river god, in others, there is the sea god while in others there are the mountain or lake gods. Those in the forest regions, as indicated earlier, have values with regard to the protection of farm produce. The Akans in the forest regions are also very much interested in inheritance. This is not to dismiss those in the coastal regions as not being interested in inheritance but there is a local joke that the Ashantis like building houses while the Fantes build houses in their stomachs. ${ }^{24}$ Of course, they are all interested in putting up houses but there are some local peculiarities in the observation above. In a situation where protection is needed for the farms and buildings, the Akan of the forest areas needvalues to protect owners or the rightful

20 Turrisi, ed. Pragmatism as a Principle and Method of Right Thinking.

21 Walter Ringwald. Die Religion der Akanstamme und das Problem Ihrer Bekeh-rung.( Stuttgart, 1952).

22 Joseph B. Danquah, The Akan Doctrine of God.( London, 1944).

${ }_{23}$ Max Assimeng. Social Structure of Ghana: a study in Persistence and Change, (Accra: Ghana Publishing Corporation, 1999).

${ }^{24}$ This assertion has no documentary source. It is a cultural joke between Fantes and Ashantis to the extent that there is a general observation in Ghana that most adverts about food are made by Fante-speaking people and most adverts on buildings are made by Ashanti Twi-speaking people. An example is "Edziban a" an advert by Kwame Dzokoto, a fanti and the DBS roofing advert by Akroboto, an Akyem. Of course, the reference to building houses as above still remains debatable but the ones that are made to the farms are valid in the sense that the people along the coastal areas go fishing and the people living in forest areas farm. 
people to inherit the property. A concept of "bosom" like Antoa, who is the god of justice is the answer. The coastal people have the same experience. In Moree (a town along the coast), the fisher folks do not go to sea on Tuesdays. They believe in the value of replenishment and regeneration and that means that one cannot go fishing throughout the week and plunder all the fish. Therefore, to preserve this value, they take one day in the week to abstain from harvesting fish and they believe that the fish can replenish and multiply for the good of the fisher folks. They, therefore, make the sea god represent this value and say that the sea god is resting on Tuesdays and it should not be disturbed on Tuesdays.

\section{Source of assignment}

The question here is: is it true that "the gods organize(d) communities such as tribes, clans, and lineages" as purported by Max Essimeng? ${ }^{25}$ In other words, the lesser gods sit far away from humans but see the weakness of humans and out of benevolence and magnanimity intervene in human lives for the good of human beings. This issue is the bone of contention here. In the first place, if this were true, the definition of the lesser gods, as has been discussed earlier, could have provided a spirit-centered one, a definition that describes the spiritual substance of the lesser gods. In the second place, there is enough literature to indicate that human beings employ the service of the gods and not the other way round. Nukunya quotes Opoku that gods who are not communally owned "are the possession of individuals who may put them to beneficial, or harmful and destructive use. ${ }^{26}$ In the ethnography of Grottanelli, there is a Nzema myth told by an elderly man called Aka Mbgasua from Atuabo to the effect that there was a period in Nzema history when the fate of the Nzema people fell on evil days. There was untold suffering and penury. Their chief was however immortal and was invited by Edenkema (the equivalent of the Christian God). He disappeared and went to God but the people felt abandoned and in their desperation, "set up a stump in the bush, dressed it in women's clothes and ornaments, and made a fetish of it." ${ }^{27}$ They worshipped it "to forget about their troubles." ${ }^{28}$ Grottanelli is not too sure of the implication of his data and he restrains himself from commenting further. About a decade later, a British by the name Karin Barber investigated exactly what Grottanelli seem to be running away from and came up with stunning results. She discovered that the Yorubas believe that the "awo" or the god, thrives on secrecy and that, "If something referred to as 'awo' has nothing in it to frighten the uninitiated, then it must not be referred to as 'awo': but if we put a stone in the gourd and make a couple of taboos to make people stop looking into it, it's become an 'awo." ${ }^{29}$ Again, Barber quotes Horton that the Kalabari people; "compare the spirits with men of influence, who are big so long as their followers follow them, and who become nothing when their followers fade away." ${ }^{30}$ She also reveals that in West Africa, humans can strip a troublesome spirit of the powers they have given it. ${ }^{31}$ Indeed, Grottanelli reports that there are a number of occasions where "the gods may not know that a sin has been committed" 32 meaning they are not omniscient. Furthermore, the observation of Barber is also prevalent among the Akans to the extent that among the Akans, a god, as powerful as it may be, may not take any action against a worshipper who denounces it and turn to worship another god. ${ }^{33}$ According to Grottanelli, lesser gods could be imported from neighbouring towns as in the case of Benya in Elmina in the Central Region and Boafo in Efiduase in the Ashanti Region. Other researchers, including Grottanelli, report that in West Africa, people can bring in a lesser god and stop worshipping it if found incapable of meeting the needs of the people. ${ }^{34}$ All these indicate that the lesser gods do not seem to have that much control over men and that the gods are at the service of men who can make them look big, small, or even dismiss them. This disputes Assimeng's assertion that it is the gods who organize the society as

25 Assimeng. Social Structure of Ghana.

26 Godwin Kwaku Nukunya, Tradition and Change in Ghana, (Accra: Ghana Universities Press, 1992)

27 Vinigi L. Grottanelli. Gods and Morality in Nzema Polytheism. Ethnology. Vol. 8, No 4, (1969): 375.

28 Grottanelli. Gods and Morality in Nzema Polytheism, 375

29 Karin Barber, How Man Makes God in West Africa: Yuroba Attitude towards the "Orisa", Africa: Journal of the International African Institute, Vol. 51, No. 3 (1981): 740.

30 Barber, How Man Makes God in West Africa, 741.

31 Barber, How Man Makes God in West Africa, 741.

32 Grottanelli, Gods and Morality in Nzema Polytheism,379.

33 Grottanelli, Gods and Morality in Nzema Polytheism, 1969.

34 Grottanelli, Gods and Morality in Nzema Polytheism, 1969. 
if to say that they generate ideas and human beings follow them. Quite clearly, it is the other way round. The assignments of the lesser gods are human and not divine designs.

\section{Creating the "fearful"}

The community assigns the god with the values that the community considers necessary for their survival. The gods are associated with all the taboos to help manage not only the sea or the forest but to see to it that social rules for peaceful co-existence are properly followed.

For these values to be followed and even internalized, they are invested in materials with uncommon features. Thus, in the Eastern Region of Ghana, there is Obour Tabiri (stone Tabiri), which is considered to be a very powerful god in Koforidua and its environs. In the Ashanti region, there is Kokofu bos, the famous stone which was the theme of a popular song in the 70s, which got mispronounced to "Kokofu ball", a kind of football game in which without a brother the ball will never be passed to a player. This is metaphorical of the power of the stone which is believed to kill anybody who sits on it and it will take friendly advice for one not to sit on it to save one's life. ${ }^{35}$ However, it is not all the time that the gods reside in stones. They are also believed to reside in rivers and thus there is Asuo Pra, Asuo Tano (River Pra, River Tano), etc. Indeed, the preponderance of the most powerful gods on Akan land are river or water gods. Pataangye in Tarkwa, Antoa Nyamaa in Antoa and but a few and the list goes on. According to Akans, there are other materials like trees, mountains, gold, stools and so forth which could serve as the abode of the lesser gods.

Also, apart from family gods, the rest are not found near human beings and they very rarely reveal their "true image" to human beings. ${ }^{36}$ When they do, the recipient has an experience like what Grottanelli reports. ${ }^{37}$ It goes like this, Honwa, one of his informants in Atuabo, had an encounter with a lesser god. He said he was collecting cotton silk in the afternoon when a female bazonle appeared to him. He described the female bazonle as being very dark in complexion and having long hairs falling on her shoulder and bosom. The breasts were huge and sagging and the apparition seemed to be coming to him with outstretched hands. The sight of the god made him faint outright. This story is not peculiar to Honwa. The conceptualization of the idea of "bosom" is therefore built on secrecy and fear. Therefore, these "abosom" 38 use scary materials that express fear, as their abode e.g. isolated groves, rivers or streams, wild or queer-looking animals, stones, etc. Hence, when "one puts a stone in the gourd and make a couple of taboos to make people stop looking into it, it's become an "awo". ${ }^{39}$ The essence of the fear factor and the spirit that "disguises" in the form of these materials is to maintain the practice of a value or values that are supposed to make the Akans play exactly according to the societal rules, failure of which amounts to falling on the wrong side of the temperament of the "bosom".

\section{Offenders are punished}

Admittedly, values like honesty, cleanliness, purity, bravery and so forth promote wonderful social order. This is however not enough; for example, one can steal from the other and admit it and that is honesty. Being honest does not stop people from stealing or being engaged in other nefarious activities so there must be a deterrent to stop people from initiating wrongdoings and the gods are assigned to do that. Even though the gods have sometimes been reported to have seen the offenders and prescribed the necessary punishment, it is the human being who tells the gods what has gone wrong. The gods investigate and see to it that justice is properly served. The same narrative goes for all the localities mentioned. For those from Antoa and its environs in the Ashanti Region, the value they cherish most is honesty. When two people have conflict over issues of honesty; for example, one is accused of stealing and one denies, the one who feels cheated takes it to the river god and if it is true that the other person is the culprit, in no time the offender's stomach starts to swell. The miscreant has another opportunity of retribution or reparation by owning up his evil deeds. Rituals will be performed and he will be healed. The same experience is found in the Western South Region, and many parts all over the

\footnotetext{
I owe this data to Dr. Daniel Owusu Ansah, Department of History, KNUST, Kumasi, 15/10/ 2017.

36 Grottanelli, Gods and Morality in Nzema Polytheism, 378.

37 Grottanelli, Gods and Morality in Nzema Polytheism,379.

38 This is the plural form of "bosom".

39 Barber, How Man Makes God in West Africa, 741.
} 
country. The Antoa god represents the community's cherished value of honesty. Therefore, honesty as a value is worshipped by the people of Antoa and that makes the representative of this value "bosom".

The values are in the form of local taboos and "death is also the penalty for the infringement of the local taboos (kyibadec) set up by individual deities." ${ }^{40}$ Grottanelli provides some data from his fieldwork to support this. ${ }^{41}$ A man and a wife who went against a taboo fell sick and had to confess their sins. The fetish priest prescribed that a sheep be slaughtered to appease the gods and the couple smeared with charcoal powder. They complied and eventually recovered. Such reactions from the gods increase the fear factor that makes the people obey social rules religiously. Eno Ataa a 72-year-old woman, tells her experience when she was young:

\section{Kane no, wode wo bosder beto ho mmre scn, obiar remmfa da. Nimpa no nim se sfa a bosom no beku no. Wode w'adec to ho a wobsba absto esiane se obiara suro se sde ne nsa beka.}

\section{Translation \\ In the olden days, one would leave his/her plantain anywhere and would come back to pick it no matter the time he spent away from it. The thief knew the gods would kill him. When one placed anything anywhere, the person would come back and find it where he/she placed it because people were afraid to touch it.}

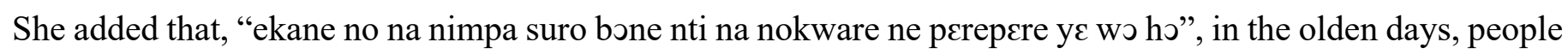
were afraid of sin so there was honesty and justice. Monsignor Raphael Owusu Pepprah added that in those days these values were the religion. ${ }^{42}$ He also attributed the fear factor to the fact that, unlike the Christian God who is not seen with the naked eye, the "bosom" or the lesser god is seen with the naked eye, at least represented in the material form and that creates a lot of scary immediacy in the relationship with the people. He goes on to say that the awesome manner in which the priests dress up, how they pour libation, how they dance, and the paraphernalia of the shrine all contribute to the fear factor.

In summary, it is clear that the "value" component of the Akan concept of "bosom" has been taken for granted in literary studies. The translation into English of this concept as "lesser gods" has not helped to capture the full meaning of this concept. The morphological and the syntactic analysis of the Akan version "bo +som" which is a derivative of "som +bo" clearly lays bare the real meaning of "bosom", that is, the worshipping of value. Some of the participants like Eno Ataa, rightly pointed out that this "value" component in the concept of "bosom" is missing out in the world today all because of colonialization which introduced the Christian God who cannot be seen and who, in the New Testament, is slow to anger, thus making it possible for the Akan Christians who no more follow the "bosom" to behave in a rather permissive manner. In so doing, they no more follow the taboos being supervised by the "abosom" and by avoiding the taboos, they drop the values that serve as a binding factor in the society; the value of honesty that promotes truthfulness, the value of care that promotes loving the neighbor, and the value of purity that promotes sexual purity and so forth. This is not to say that these values are not in Christianity but Christianity falls short of presenting them without the fear factor unlike how the traditional Akan concept of "bosom" presents them. In the story told in the previous section, it is true that it was not a man who was responsible for the sickness of the couple. Nonetheless, it is a man who created the taboos where a breach can bring about terrible consequences. These negative consequences from the "bosom" are swift, unlike the delayed consequences in Christianity. Today, as reported by Grottanelli, most Nzemas, and of course most Akans, have stopped following the concept of "abosom". According to him, all these Nzemas who have left worshipping the bazonle or "bosom" do is to go to the bazonle with libation asking that they are no more with the bazonle and are now Christians and by so doing are now not limited by the values of the "bosom".

\footnotetext{
40 Grottanelli, Gods and Morality in Nzema Polytheism. 382.

41 Grottanelli, Gods and Morality in Nzema Polytheism. 383.

42 Interview with Monsignor Raphael Owusu Pepprah, Cathedral Basilica of Kumasi Catholic Archdiocese, 13/11/2020.
} 


\section{CONCLUSION}

This paper interrogates the role Akan poetics play in revealing beliefs and the philosophy that influences, even though to a lesser degree in the modern times, the thinking of the Akan people for a better social organization. It is clear the Akans but not the "bosom" construct the taboos and that these taboos are values that guide their behavior. The Akan concept of "bosom" is therefore part of a grand social constructivist approach by the Akan people to organize the society for the purpose of peace and order. It is one of the agents of Akan socialization that makes the Akan behave in the way of the community and makes them conform to the communalistic ideals of that society. This development is a reminder that the anthropology of the text constitutes the "documents of native mentality." 43 According to Malinowski, this helps the ethnographer to "grasp the native's point of view, his relation to live, to realise his vision of his world." This Akan worldview is, however, not as strong as it used to be because of foreign influences.

\section{ABOUT AUTHOR}

Peter Arthur $(\mathrm{PhD})$ is a Senior Lecturer in the Department of English, Kwame Nkrumah University of Science and Technology, Kumasi-Ghana.

\section{BIBLIOGRAPHY}

Agyekum, Kofi. Ntam 'reminiscential oath' taboo in Akan, Language in Society, 33, (3), (2004): 317-342. Agyekum, Kofi. Akan Body Parts Expressions: Cognitive Semantics and Pragmatic Approach, Accra: Adwinsa Publications (Gh) Ltd., 2018.

Assimeng, Max. Social Structure of Ghana: a study in Persistence and Change, Accra: Ghana Publishing Corporation, 1999.

Barber, Karin. How Man Makes God in West Africa: Yuroba Attitude towards the "Orisa", Africa: Journal of the International African Institute, 51 (3), (1981),

Becher-Leckrone, Meghan. Julia Kristeva and Literary Theory. London, Palgrave Macmillan, 2005.

Chomsky, Naom. Language and Mind. Harcourt Brace Jovanovich, Inc, 1972.

Danquah, Joseph B. The Akan Doctrine of God. London, state the publisher 1944.

Dolphyne, Abena F. The Akan (Twi-Fante) Language.: Its Sound System and Tonal Structure.Accra: Ghana Universities Press, 1988.

Grottanelli, Vinigi. L. Gods and Morality in Nzema Polytheism. Ethnology. 8 (4), 1969.

Huang, Yu. The Application of Stylistic Analysis in College English Teaching, Advances in Economics, Business and Management Research, 75, (2019): 554-557.

Joseph, John. E. From Whitney to Chomsky: Essays in the History of American Linguistics. State the city of publication John Benjamins, 2002.

Kluckhohm, Florency and Fred Strodtbeck, quoted in Spates, J. L. The Sociology of Values, Annual Review in Sociology, 9, (1961): 27-49.

Lazzeri, Filipe. On defining behavior: Some notes, Behavior and Philosophy, 42, (2014): 65-82.

Marfo, Charles. and SolaceYankson. The Structure of the CCV Syllable of Akan. Concentric: Studies in Linguistics, 34 (2) (2008): 85-100.

Nukunya, Godwin, Kwaku. Tradition and Change in Ghana, Accra: Ghana Universities Press, 1992.

Ringwald, Walter. Die Religion der Akanstamme und das Problem Ihrer Bekeh-rung. (Stuttgart, insert name of publisher 1952).

Sapir, Edward. quoted in Paul Kay and Willet Kempton, What is Sapir-Whorf Hypothesis? American Anthropologist. 86 (1), (1929): 65-79.

Spates, James, L. The Sociology of Values, Annual Review in Sociology, 9, 27-49.

Stekauer, Pavon and Rochelle Lieber. eds. Handbook of Word-formation, Dordredtch: Springer, 2005.

\footnotetext{
${ }^{43}$ Michael W.Young. The Intensive Study of Restricted Area, Or, Why did Malinowski Go to the Trobriand Island? Oceania, 55, no.1, 1984, 24.
} 
Turrisi, Patricia Ann ed. Pragmatism as a Principle and Method of Right Thinking: the 1903 Harvard Lectures on Pragmatism by Charles Sanders Peirce. State University of New York Press, Albany, New York, 1997.

Whorf, Benjamin Lee. Science and Linguistics. In Language. Thought and Reality. John B. Caroll, ed. Cambridge, Mass: M. I. T. orig. pub. In Technology Review. 42 (1929): 229-231, 247-248.

Yankah, Kwesi. The Proverb in the contect of Akan rhetoric; a theory of proverb praxis, New York: Bern, 1989.

Young, Michael, W. The Intensive Study of Restricted Area, Or, Why did Malinowski Go to the Trobriand Island? Oceania, 55 (1)(1984): 1-26. 